\title{
SEASONALITY OF USE OF ZA HÁJOVNOU CAVE BY BEARS AND LIONS
}

\author{
MIRIAM NÝVLTOVÁ FIŠÁKOVÁ \\ Archeological Institute AS CR Brno, v.i.i., Královopolská 147, 612 00, Brno, the Czech Republic; e-mail: nyvltova@arub.cz
}

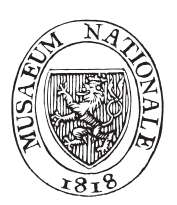

Nývltová Fišáková, M. (2014): Seasonality of use of Za Hájovnou Cave by bears and lions. - Acta Mus. Nat. Pragae, Ser. B, Hist. Nat, 70(1-2): 103-106, Praha. ISSN 1804-6479.

\begin{abstract}
Dental cementum from lions (Panthera fossilis) and bears (Ursus deningeri) found in Za Hájovnou Cave in Javoříčko Karst were studied. In order to determine the reasons why bears and cave lions crawled into the cave, tooth cement increments were analysed. I used thin sections of the tooth roots of these mammals to determine the seasonality of the death. The tooth samples were taken from different parts of the cave complex: Chodba naděje, Kostnice II, Narozeninová chodba and Propástka 1. These data indicate that bears mostly sought out this cave as a place to hibernate. The exception was one specimen which died there between spring and summer, probably as the result of illness or injury. Five bears died in the early stages of hibernation and seven during winter. In the case of the cave lions (Panthera fossilis), these were predominantly young and thus inexperienced and were therefore probably attracted by the bear carcasses in the caves. It is highly likely that these carcasses attracted not only young and inexperienced lions, but also other predators (such as hyenas, or adult lions). Za Hájovnou Cave was probably used as a winter den by bears and especially by expectant mothers for the birth of their cubs. Other species present may be there due to predatory activity or were exploiting the carcasses of dead bears during the winter.
\end{abstract}

Middle Pleistocene, thin sections, seasonality, caves, the Czech Republic

Received January 20, 2014

Issued October, 2014

\section{Introduction}

Analysis of dental cement increments of lions from $\mathrm{Za}$ Hájovnou Cave complex were conducted to determine whether the lions occurred there together with bears (and were hunted or stoked on carrion) or have never met there. We used thin sections of tooth roots from these mammals to determine seasonality of their death.

\section{Material and methods}

All the studied fossil material is deposited in the Moravian Museum in Brno.

The fossil material is very fragmentary. When selecting suitable teeth for analysis, stratigraphic position and the presence of lion remains in the same layer as the teeth of a bear (Ursus deningeri) has to be taken into consideration. Unfortunately, due to the fragmented state only three lion teeth conform to this requirement (see Table 1).

Cement accrues throughout the life of an individual. The rate of cement accretion is not constant over the entire year: it is more intense during the growing period (April to October), when there is plenty of food; while during dormancy (November to March), the growth rate is slower because of the limited food supply (the equivalent of growth rings in trees). The winter layer begins to form in November and finishes in April. The summer layer begins to form in May. The annual increment is composed of light and dark summer and winter increments formed due to various activities of the cementoblasts, which are influenced by the relative percentage of mineral and organic constituents in the diet (Carlson 1991, Debeljak 2000, Ábelová 2005, Hillson 2005). For analysis, it is necessary to determine the thickness of individual winter and summer layers and thus the time elapsed from the beginning of increment formation (from May or from November) in the mammal species can be determined (Lieberman et al. 1990, Carlson 1991, Lakota-Moskalewska 1997, Debeljak 2000, Ábelová 2005, Nývltová Fišáková 2007, 2013). To calculate the dental age using cement increments, the time that elapsed between the birth of an animal and specific permanent tooth eruption must be added. If we study cement increments in canine teeth and final molars (M2, m3) as a means of determining the age of an individual, half to one year for canines and half to three and a half years must be added for molars, depending on the animal species in question (Debeljak 1997, Červený et al. 1999; Komárek et al. 2001). According to the type of animal, milk teeth originate during prenatal development and the animal is born either with milk teeth (e.g. piglet with Id3 and $\mathrm{Cd} 1$ - incisivus et canin decidua, i.e. milk incisor and canine), or they are cut at birth or within the first weeks of the individual's life. The first permanent teeth usually appear between three to six months of age and the time of eruption is species typical (Debeljak 1997, Červený et al. 1999, Komárek et al. 2001). Weathering of the tooth leads to destruction of the upper tooth parts which negatively affects the cement. Therefore, in some cases, age and season of death of the animal, cannot be determined (Debeljak 1997, Ábelová 2005).

The individual animal species and teeth, including location of the finds, interpreted age and season of death are shown in Table 1.

The teeth samples were taken from different parts of the cave: Chodba naděje (= Corridor of Hope; layers 3 and 4), 
Table 1. Location, species, age and season of death of bears (Ursus deningeri) and cave lions (Panthera fossilis) from Za Hájovnou Cave, Javoříčko Karst.

\begin{tabular}{|l|c|c|c|c|}
\hline \multicolumn{1}{|c|}{ Localisation } & Animal species & Tooth type & Dental age & Season of death \\
\hline Narozeninová chodba, layer 2b & Ursus deningeri & caninus & 8 years & II-IV \\
\hline Chodba naděje, layer 4 & Ursus deningeri & caninus & 10 years & V-VII \\
\hline Chodba naděje, layer 3 & Panthera spelaea & p4 sin & 1.5 years & II-IV \\
\hline Kostnice II, 2a, 3b & Panthera spelaea & $\mathrm{p} 3$ & 2.5 years & V-VII \\
\hline Chodba naděje, layer 3 & Panthera spelaea & $\mathrm{m} 1$ dex, & 2 years & V-VII \\
\hline Propástka 1, layer 3 & Ursus deningeri & i3 sin, & 2 years & XI-I \\
\hline Chodba naděje, layer 3 & Ursus deningeri & caninus & - & - \\
\hline Kostnice II, 2a, 3a, 3b, dump & Ursus deningeri & premolar & 9 years & X-XII \\
\hline Chodba naděje, layer 5, brown clay & Ursus deningeri & i3 & 11 years & X-XII \\
\hline Narozeninová chodba, Propástka 2, layer 5, brown layer & Ursus deningeri & premolar & 9 years & XI-I \\
\hline Narozeninová chodba, Propástka 2, layer 2b, brown layer, dph 9.3 m & Ursus deningeri & p4 & 3 years & X-XII \\
\hline Narozeninová chodba, Propástka 2, layer 2b, brown layer, dph 9.3 m & Ursus deningeri & i3 & 7 years & X-XII \\
\hline Narozeninová chodba, Propástka 2, layer 2b, brown layer, dph 9.3 m & Ursus deningeri & i2 & 2 years & X-XII \\
\hline Narozeninová chodba, Propástka 2, complex 3, dph 9.3 m & Ursus deningeri & m3 & 8 years & II-IV \\
\hline Narozeninová chodba, Propástka 2, complex 3, dph 9.3 m & Ursus deningeri & caninus & 8 years & II-IV \\
\hline
\end{tabular}

Kostnice II (= Charnel-House II; layers 2a, 3a and 3b), Narozeninová chodba - Propástka 2 (= Birthday Corridor Abyss II; layer 2b), depth $9.3 \mathrm{~m}$ and Propástka 1 (= Abyss I; layer 3).

A detailed description of each layer and their stratigraphy is given in Musil (2014). Most of the studied fossil lion and bear material comes from the Middle Pleistocene interglacials (MIS 11? - 9) - see Sabol (2014).

\section{Results}

Dental age of the animals and the season in which they died are presented in Table 1.

\section{Narozeninová chodba, Propástka 2, ZH P-9, (layer 5, depth $9.3 \mathrm{~m}$ )}

A total of six teeth were analysed from this part of the cave (a canine, third lower molar, second and third lower incisor and fourth lower premolar and a premolar). On the basis of tooth dental cementum increments, it was found that the canine and third lower molar possibly belonged to the same individual who had died at the age of 8 years during hibernation between winter and early spring (II-IV). The other three specimens died between autumn and winter at the ages of 2, 3 and 7 years. The last animal died at the age of 9 years while hibernating during the winter (see Table 1, Text-fig. 8).

\section{Narozeninová chodba - layer $2 \mathrm{~b}$}

One bear specimen (Ursus deningeri) was analysed from this location. This bear died at the age of 8 years during hibernation - see Table 1 and Text-fig. 1.

\section{Chodba naděje, ZH P-7 - layer 3}

A total of three teeth were analysed from this layer: two fourth lower premolars and the first lower molar from two cave lions (Panthera fossilis) and one canine from a bear

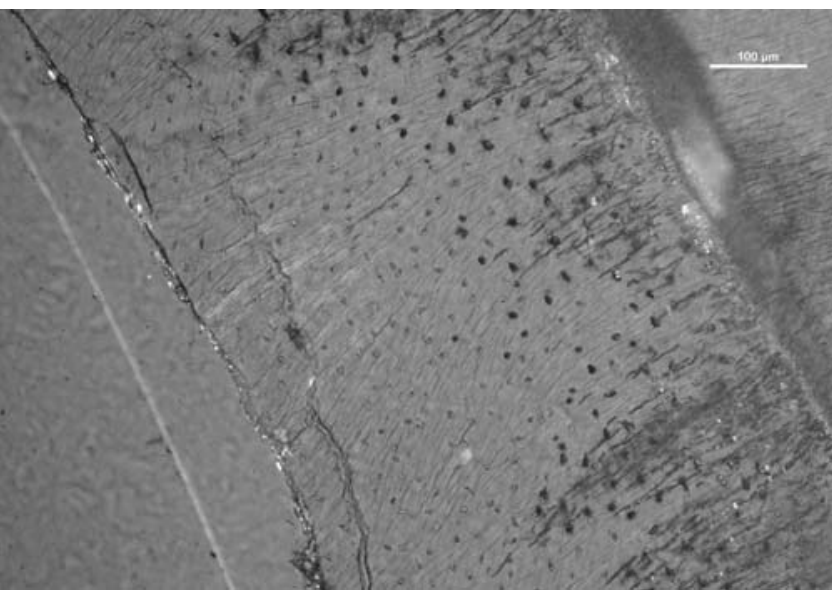

Text-fig. 1. Thin section of canine from a bear (Ursus deningeri), Narozeninová chodba, layer $2 \mathrm{~b}$.

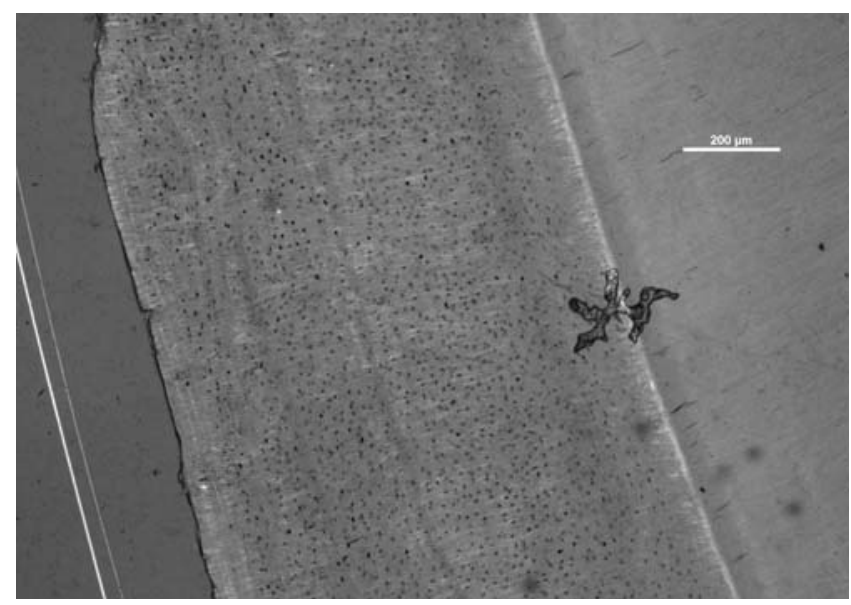

Text-fig. 2. Thin section of canine from a bear (Ursus deningeri), Chodba naděje, layer 4, depth $140-200 \mathrm{~cm}$.

(Ursus deningeri). One lion died at the age of 1.5 years during the winter, the second at the age of 2 between spring and summer. Cement accretions were not preserved in the bear canine. See Table 1 and Text-figs 3 and 5. 


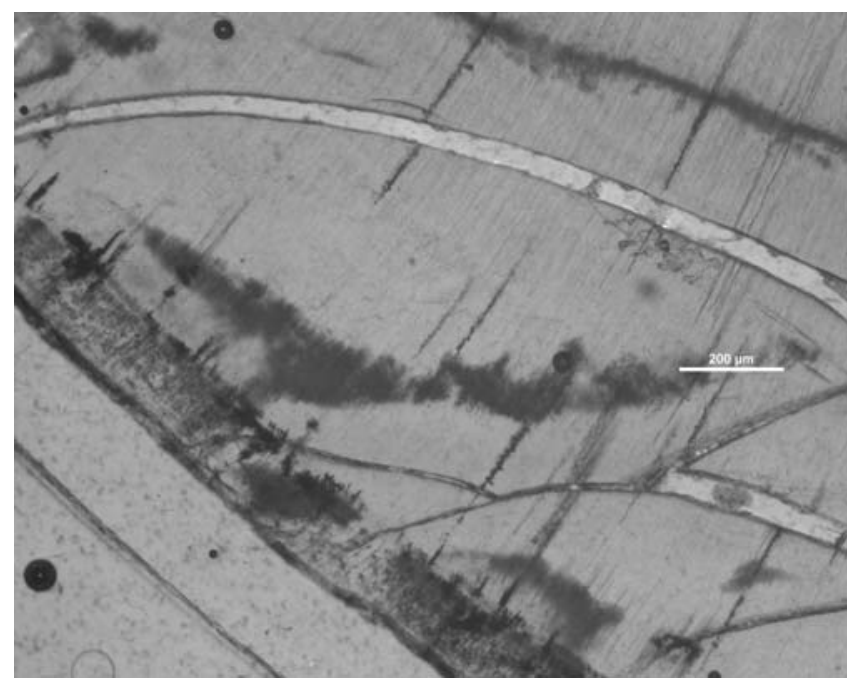

Text-fig. 3. Thin section of fourth premolar from a cave lion (Panthera spelaea), Chodba naděje, layer 3.

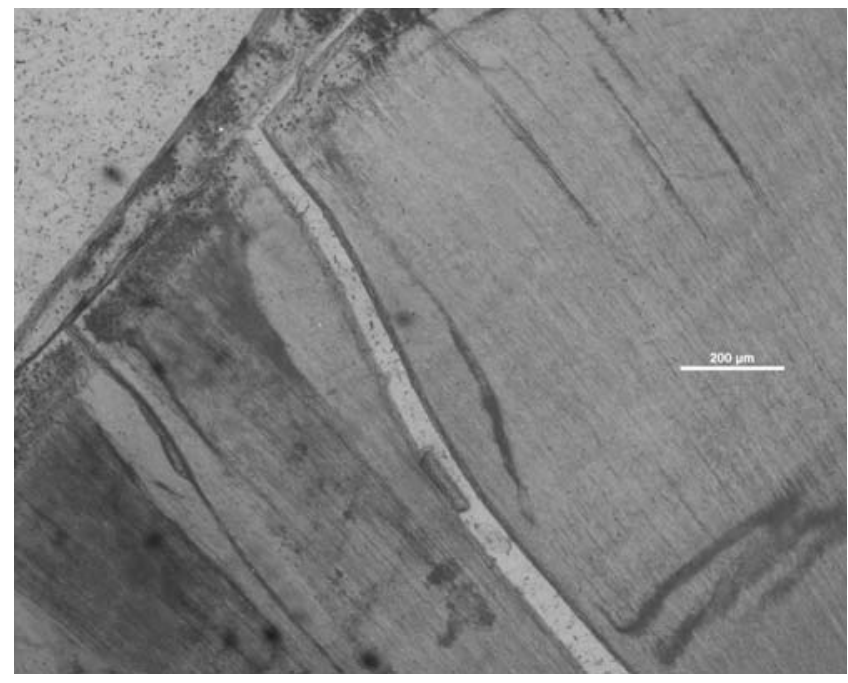

Text-fig. 4. Thin section of premolar from a cave lion (Panthera spelaea), Ossuary II, 2a, 3b.

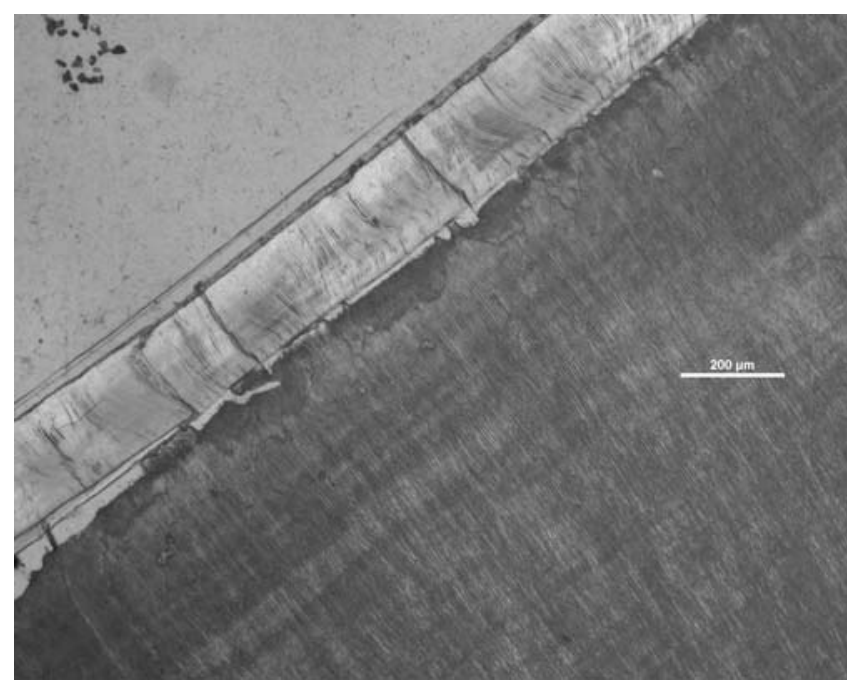

Text-fig. 5. Thin section of molar from a cave lion (Panthera spelaea), Chodba naděje, layer 3.

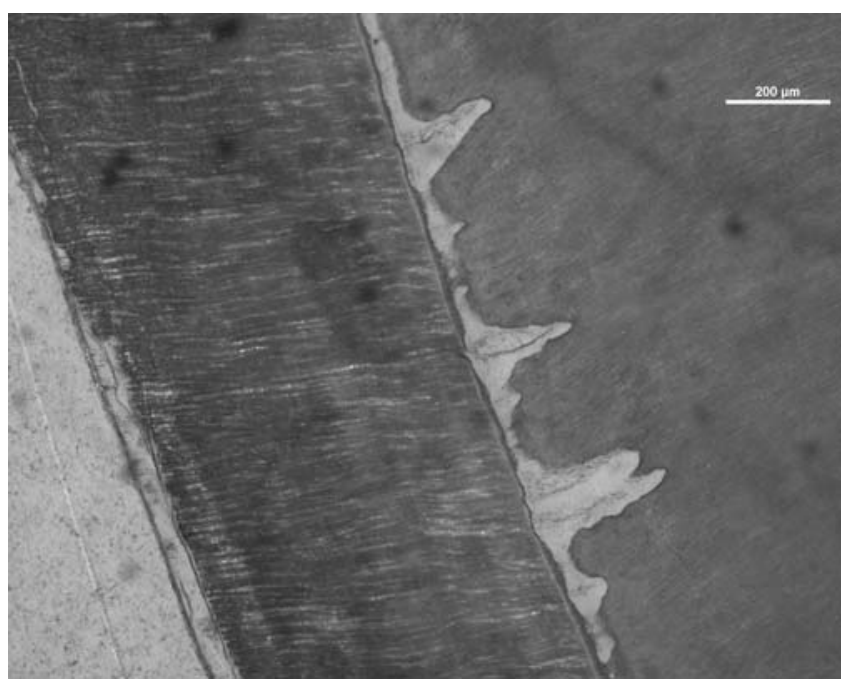

Text-fig. 6. Thin section of third lower incisor from a bear (Ursus deningeri), Propástka 1, layer 3.

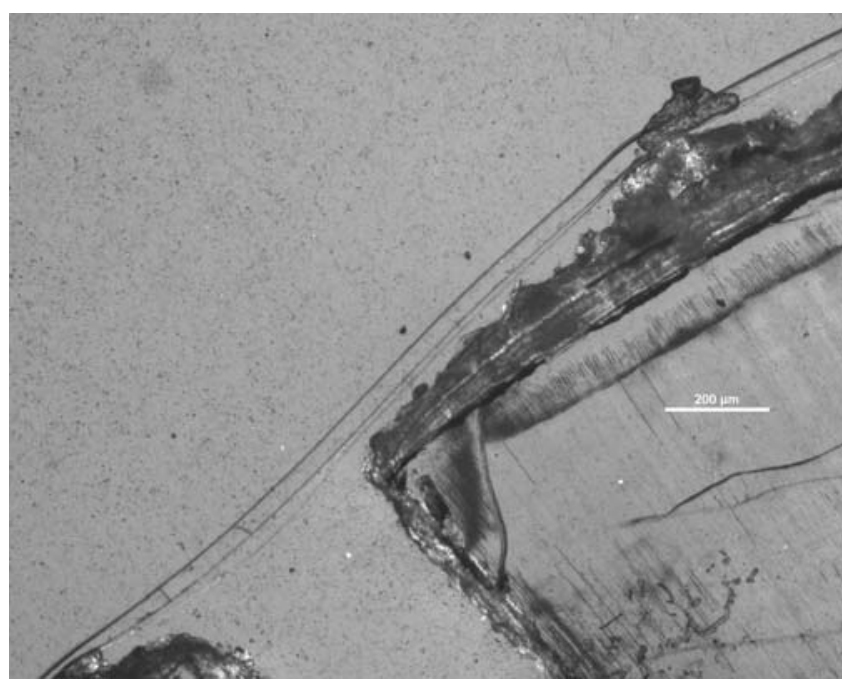

Text-fig. 7. Thin section of premolar from a bear (Ursus deningeri), Kostnice II, layer 2a, 3a, 3b - dump.

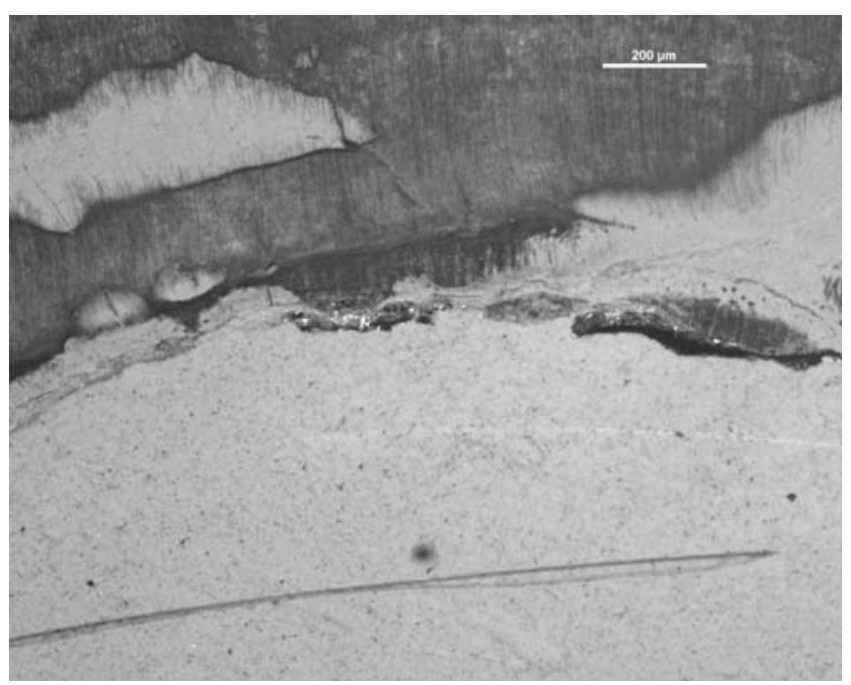

Text-fig. 8. Thin section of third lower incisor from a bear (Ursus deningeri), Chodba naděje, layer 5. 


\section{Chodba naděje, ZH P-7 - layer 4}

The only tooth studied from this layer was a canine from a bear (Ursus deningeri). This bear died at the age of 10 years between spring and summer. Moreover, this bear most probably died during the summer, as the result of an accident or injury. See Table 1 and Text-fig. 2.

\section{Chodba naděje, ZH P-7 - layer 5}

From this layer we studied the third lower incisor (i3) of a bear (Ursus deningeri) which had died at the age of 11 years in the first months of hibernation - see Table 1 and Text-fig. 8.

\section{Kostnice II - layers $2 a$ and $3 b$}

From Kostnice II we analysed a third premolar from a cave lion (Panthera fossilis) and a premolar from a bear (Ursus deningeri). The lion died during the summer at the age of 2.5 years and the bear died between autumn and winter at the age of 9 years - see Table 1 and Text-figs 4 and 6 .

\section{Discussion and conclusions}

These results indicate that bears mostly sought out this cave as a place to hibernate and give birth to cubs during hibernation, based on analysis of the sex ratio, which indicated a predominance of females (Sabol 2014). These findings are consistent with other sites in the world containing remains of this bear species (Ursus deningeri) (García et al. 1997, Stiner 1998, Sabol 2014). The exception is one specimen which perhaps died between spring and summer, probably as the result of illness or injury. Five bears died during the early stages of hibernation and seven during the winter. In the case of cave lions, they were predominantly young animals, not yet skeletally mature, which were inexperienced hunters and were therefore attracted by the bear carcasses in the caves. The presence of young lions in the studied material is random because these were the only preserved teeth samples suitable for this kind of analysis. It is highly likely that these carcasses attracted not only young and inexperienced lions, but also other predators (such as hyenas, lions or other adult bears), which probably outnumbered the young lions, and these young lions maybe lost the fight over the prey.

This cave certainly did not serve as a den for hyenas as was suggested by Diedrich (2011) in his work on caves in the Bohemian Karst, but it was rather a winter habitat for bears, where the bears died and their carcasses attracted other predators, including lions.

\section{References}

Ábelová, M. (2005): Analýza mikrostruktur zubného cementu medved'ov (Ursidae) [Microstructure of the dental cement of bears (Ursidae)]. - Geologické výzkumy na Moravě a ve Slezsku v roce 2004: 2-4. (in Slovak)

Carlson, S. J. (1991): Vertebrate Dental Structures. - In: Carter, J. G. (ed.): Skeletal Biomineralization: Patterns, Process and Evolutionary Trends, Van Nostrand Reinhold, New York, pp. 531-556.

Červený, Č., Komárek, V. Štěrba, O. (1999): Koldův atlas veterinární anatomie [Kolda's Atlas of Veterinary Anatomy]. - Grada-Avicenum, Praha, 701 pp. (in Czech)

Debeljak, I. (1997): Ontogenic development of dentition in the cave bear. - Geologija, 39: 13-77.

Debeljak, I. (2000): Dental cementum in the cave bear; comparison of different preparation techniques. Geološki zbornik, 15: 25-40.

Diedrich, G. C. (2011): Late Pleistocene Panthera leo spelaea (Goldfuss, 1810) skeletons from the Czech Republic (central Europe); their pathological cranial features and injuries resulting from intraspecific fights, conflicts with hyenas, and attacks on cave bears. Bulletin of Geosciences, 86(4): 817-840.

García, N., Arsuaga, J. L., Torres, T. (1997): The carnivore remains from the Sima de los Huesos Middle Pleistocene site (Sierra de Atapuerca, Spain). - Journal of Human Evolution 33: 155-174. http://dx.doi.org/10.1006/jhev.1997.0154

Hillson, S. (2005): Teeth. Cambridge Manuals in Archaeology. - Cambridge University Press, Cambridge, 358 pp.

Komárek, V., Štěrba, O., Fejfar, O. (2001): Anatomie a embryologie volně žijících přežvýkavců [Anatomy and embryology of wild ruminants]. - Grada-Avicenum, Praha, 449 pp. (in Czech)

Lakota-Moskalewska, A. (1997): Podstawy Archeozoologii [Principles of Archaeozoology]. - Wydawnictvo Naukowe PWN, Warszawa, 232 pp. (in Polish)

Lieberman, D. E., Dracén T. W., Meadow, R. H. (1990): Computer image enhancement and analysis of cementum increaments as applied to teeth of Gazela gazela. Journal of Archaeological Science, 17: 98-124.

Musil, R. (2014): The unique record of Za Hájovnou Cave. - Acta Mus. Nat. Pragae, Ser. B, Hist. Nat, 70(1-2): 7-26.

Nývltová Fišáková, M. (2007): Sezonalita gravettských lokalit na základě studia mikrostruktur zubního cementu savců [Seasonality of Gravettian sites on the basis of mammalian dental cement microstructure]. - Přehled výzkumů, 48: 13-23. (in Czech)

Nývltová Fišáková, M. (2013): Seasonality of Gravettian sites in the Middle Danube Region and adjoining areas of Central Europe. - Quaternary International, 294: 120-134.

Sabol, M. (2014): Basic Population and Taphonomic Analysis of Bear Assemblages from Za Hájovnou Cave (Moravia, the Czech Republic): a Fossil Record from 1987-2007. - Acta Mus. Nat. Pragae, S.B., Hist. Nat. 70(1-2): 91-102.

Stiner, M. (1998): Mortality analysis of Pleistocene bears and its paleoanthropological relevance. - Journal of Human Evolution, 34: 303-326. http://dx.doi.org/10.1006/jhev.1997.0198 